\title{
Abdullah Kaya* and I-Tsung Tsai \\ Inclusive Economic Institutions in the Gulf Cooperation Council States: Current Status and Theoretical Implications
}

DOI 10.1515/rmeef-2015-0015

Published online July 30, 2016

\begin{abstract}
While the social conflict theory (SCT) suggests that absolute monarchies will not tolerate inclusive economic institutions, the Gulf Cooperation Council (GCC) countries have regularly achieved above global average ratings for property rights protection, entry barriers, disruptive wealth redistribution and corruption. This paper discusses the extent to which GCC states have potential to further improve their institutional quality. We explore whether inclusive economic institutions may emerge in GCC states, such as: (1) regional economic integration and competition which alleviate rulers' capability to expropriate private property and ease entry barriers to the market, (2) rulers of resource rich economies sustain political power with control of natural resources as opposed to the extraction of private property; and (3) prospect of long-term gain for the ruler incentivizes the adoption of a market-based economy. Strong state involvement in manufacturing and the monopoly of some services, the effect of tribalism in economic affairs and the distribution of resources, as well as a sponsorship system for foreign workers in these states may all impede the development of a truly competitive and free economy.
\end{abstract}

Keywords: political and economic institutions, Gulf Cooperation Council, rentier states

\section{Introduction}

Institutions play a critical role in economic development (North 1990; Knack and Keefer 1995; Clague et al. 1999; Acemoglu et al. 2000; Rodrik et al. 2004). These institutions comprise organizations, laws, rules of game, beliefs and norms which together shape the way economic activities perform (Greif 2008; North

\footnotetext{
*Corresponding author: Abdullah Kaya, Masdar Institute of Science and Technology, Abu Dhabi, UAE, E-mail: akaya@masdar.ac.ae

I-Tsung Tsai, Masdar Institute of Science and Technology, Abu Dhabi, UAE,

E-mail: itsai@masdar.ac.ae
} 
1990, 2008). Shirley (2005) categorizes institutions into two types: (1) the subject and, normally, hidden type which concern habits, beliefs and human capital and (2) the objective and explicit type which include constitutions, laws, government type (democracy or monarchy) (North 1990). Rodrik, Subramanian, and Trebbi (2004) show that quality of institutions has greater power in explaining the difference of economic performance among countries than do other factors such as geography or level of integration with the world economy.

Acemoglu, Johnson, and Robinson (2005) define inclusive economic institutions as a set of law and social establishments that enforce contract, protect property rights, and ensure equality of legal rights to economically empower the broader population. While inclusive economic institutions have been shown to be the most efficient in facilitating economic development, empirical analyses suggest that inclusive economic institutions are unlikely to emerge in monarchies due to the fear of political power change (Acemoglu, Johnson, and Robinson 2005; Acemoglu 2008). This paper analyzes the status of inclusive economic institutions in the GCC countries (Bahrain, Kuwait, Oman, Saudi Arabia, Qatar, and UAE). These six countries have an absolute political system in which power is concentrated primarily in the hands of the rulers or the ruling families. Any attempt to diversify the economy away from hydrocarbon revenues would give a broader group of the population access to economic opportunities. This paper analyzes whether GCC countries have been able to develop inclusive economic institutions under the absolutist political structure.

Inclusivity of economic institutions is difficult to measure as it comprises qualitative characteristics such as the stringency of legal systems or interactions among various institutions affecting a certain outcome (Knack and Keefer 1995; Acemoglu, Johnson, and Robinson 2005). As a result, most empirical studies perform either surveys or case studies to analyze economic inclusivity (Lall 2001; Howell 2011). In this paper, we propose to assess the economic inclusivity of a country with regard to its performance in property rights protection, entry barriers, disruptive wealth redistribution and corruption. We use the indexes complied by the Economic Freedom of the World (EFW), World Economic Form and other reports to assess the quality of property rights protection and level of entry barrier of the GCC countries. Following Acemoglu (2003), the level of taxation is used to measure distortionary wealth distribution. The Transparency International Corruption Index is used to measure the level of corruption.

The results show that GCC countries have achieved above or around the world average in the four measurements. In particular, Qatar and UAE have consistently achieved high rankings in most indicators. Kuwait, Oman and Saudi Arabia were generally on the world average for protection of property rights and 
entry barriers and perform weaker in perceived corruption. Bahrain has weaker performance for legal system and private property protection and entry barriers. Distortionary wealth redistribution is minimal, or not explicit, with neither income tax nor value-added tax in the GCC states. Up to now, GCC states have had good performance on institutional quality regarding the economy.

Nevertheless, GCC countries are facing increasing pressure to finance government spending which is crucial for the domestic stability of these states. Thanks to advancement in shale oil, Canadian tar sands, and offshore oil technologies, there is an ever growing supply which has culminated in a sharp drop of oil price amid a sluggish worldwide demand (Arezki and Blanchard 2014). Many experts and organizations such as International Energy Agency predict that recovery of oil price to a point where some GCC states balance their budgets may not be realized before 2020. Coupled with invention of new oil technologies and the discovery of new oil deposits, increasing efforts of decarbonizing global economy put further serious doubt on future value of oil (Goodstein and Gass 2004). Most GCC states will be running significant budget deficits with the current oil price level, a trend which may continue due to increases in population and of domestic energy use (Al-Khatteeb 2015). The average global price of oil is considerably lower than the oil price needed to balance the budgets of GCC states from the years 2014-2016 with the exception of Kuwait (Figure 1).

FiscalBreakeven Oil Prices for GCC States and Average Oil Price 2015 in USD (per Barrel)

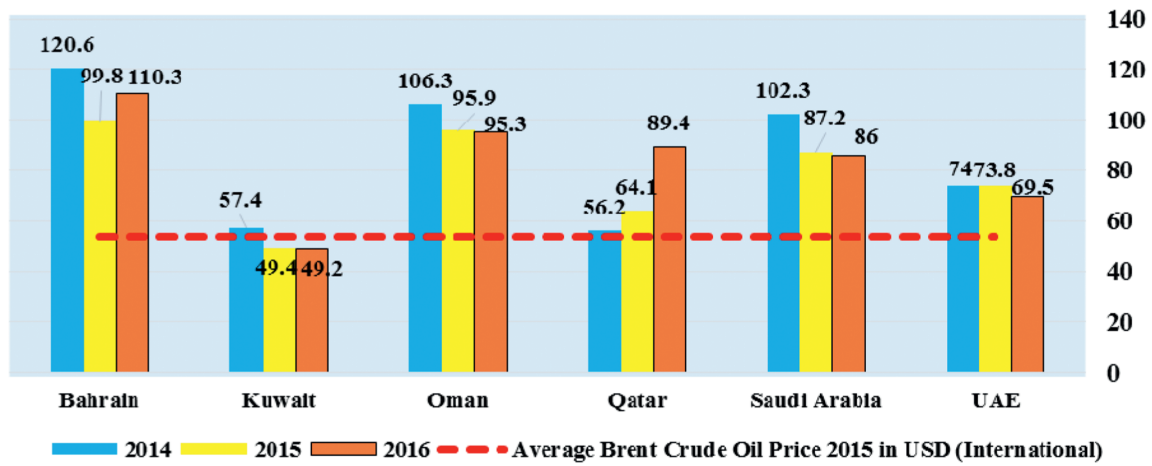

Figure 1: Fiscal breakeven oil prices for GCC states for 2014-2016.

Source: Al-Khatteeb 2015; and oil price from eia.org.

GCC states need to use their reserve money or start borrowing from private agents to fill the hole in their state budgets. Neither of these options are 
sustainable in the long run as pointed out by IMF (Al-Khatteeb 2015). The long touted diversification of the economy has become a priority in GCC states, being the only viable option to maintain the citizens' well-being and hence security of the rentier system (Hertog 2013). Successful diversification of GCC economies away from hydrocarbon businesses requires further inclusivity in economic institutions that are proved to be critical for economic development and growth.

Three schools of thought provide rationale for the emergence of inclusive economic institutions in the GCC countries: (1) market-preserving federalism theory (MPFT): regional economic integration and competition which alleviates the ruler's capability of wealth extraction from the population, (2) the rentier state theory (RST): rulers of resource rich economies sustain political power with control of natural resources and accrued rent revenues instead of extractive institutions on the economic output; and (3) the political Coase theory (PCT): in which tradeoffs between short-term versus long-term gains undermine rulers' motivation for rent extraction. While entry barrier is not perceived as being a significant factor in the GCC states, we suggest that the governments' heavy direct involvement in the economy and tribalism are likely to introduce implicit entry barriers.

The remainder of the paper is structured as follows: Section 2 reviews the theory of inclusive economic institutions and social conflicts. Section 3 presents the structure of political institutions in the GCC States. Section 4 identifies two unique features of economic institutions of the GCC states. Section 5 examines the performance of economic inclusivity in the GCC states. Section 6 introduces three relevant theories that may explain the emergence of inclusive economic institutions in the GCC states. Section 7 concludes and discusses the findings.

\section{Theories on Inclusive Economic Institutions and Social Conflict}

The quality of institutions is shown to be a dominant factor in explaining differences in economic performance, measured as GDP per capita, across countries (North 1990; Weingast 1995; Clague et al. 1999; Acemoglu et al. 2000). Ever since Douglas North's seminal work (North 1990), the study of the role of institutions in economic performance has grown significantly (Davis 2010). This school of thought claims that institutions are the key and causal factor behind economic development as opposed to others, which focus on the effects of climate or geography (Myrdal 1968; Bloom et al. 1998), culture (Greif 2008), natural endowments, or genetic makeup of the population. Acemoglu, 
Johnson, and Robinson (2000) use "early settler mortality" rate of Europeans in the new world territories (US, Canada, Australia, Latin America, Africa and other former colonies) as a proxy to explain the root of different economic institutions currently prevailing in these formerly colonized states. ${ }^{1}$ They showed that $75 \%$ of income difference across the former colonies of Europe can be explained by differences in economic institutions. The role of institutions in economic performance has been vindicated by other empirical studies (Knack and Keefer 1995; Rodrik, Subramanian, and Trebbi 2004; Clague et al. 1999; Mehlum, Moene, and Torvik 2006; Apergis and Payne 2014).

There are two types of institutions: economic and political. North (1990) describes economic institutions as human-devised rules (constitution and its practice) that govern economic activities, norms of behavior among economic agents, and contract enforcement. The performance of the economic institutions can be measured by the efficiency of markets where transactions of goods and services take place (Pirenne 1937). Acemoglu, Johnson, and Robinson (2005) studied the emergence of institutions with an analysis of the two Korean states. They showed that the main differences between the Southern and the Northern states are the direct results of institutions rather than differences in ideology, culture or geography. While North Korea chose an authoritarian regime with the government entitled to everything in the country and control rights to all economic activities, South Korea embraced individual property rights, free markets and an independent judiciary. Despite North Korea's greater endowment of mineral sources and heavy industry buildup left by Japanese Rule, South Korea's economy has grown much faster than North Korea's economy since the separation of the two states in 1959.

Political institutions, on the other hand, include laws, regulations and the enforcing bodies that govern the operations of labor and financial markets, entry conditions to markets, distribution of the wealth through taxation or rent distribution (land, license etc.) (Acemoglu 2003; Acemoglu, Johnson, and

1 There were concerns that "early settler mortality" could be a weak instrument for quality of institutions, which means that two variables are not correlated to each other strongly, thus potentially making the analysis of Acemoglu, Johnson, and Robinson (2000) problematic (Albouy 2004). However, Chernozhukov and Hansen (2008) refute this proposition by weak instrumental regression approach for the effect of "early settler mortality" on quality of institutions. If there was weak instrumental problem, then the interval for regression coefficient of "early settler mortality" on institutions should contain 0 or dangerously close to zero. However confidence interval of the parameter is between 0.662 and 1.667 with $95 \%$ confidence level (Chernozhukov and Hansen 2008). Their finding indicates that it is statistically valid to use "early settler mortality" as an instrument in measuring quality of institutions. 
Robinson 2005). Political institutions shape economic institutions which affects future distribution of political power. The two institutions thus interact in an ever-evolving dynamic system (Acemoglu, Johnson, and Robinson 2005). The functionality and the emerging pathway of the legislative authority are the major subjects in the analysis of political institutions due to the fact that legislative authority directly creates the rules of economic activities (Groenewegen and van der Steen 2007). The power of the government and its strategies are important determinants in policy transparency, strength of the law, as well as corruption (Reed 2001). Clague et al. (1999) claim that governments are third-party enforcer of contracts, of peace keeping and are creators of rules regarding economic activities. On the other hand, governments can be sources of corruption, property expropriation or inefficient and unfair welfare distribution (Clague et al. 1999; Acemoglu, Johnson, and Robinson 2005). A judiciary system and its structure is also critical in the implementation of laws and regulations and the monitoring of economic activities (Parolin 2006). The analysis of Acemoglu, Johnson, and Robinson (2005) of colonized countries in Europe shows that economic institutions are the main reason for income and development differences across countries. In regions with larger European settlements and limited natural resources for extraction, such as the USA, Canada and Australia, economic institutions that respect property rights and support market-based economic activities were established. In regions with a large indigenous population and a lot of natural sources to extract, such as Chile, Peru, etc., European settlers established "extractive economic institutions" to maximize the collection of rent.

Mehlum, Moene, and Torvik (2006) construct a specific theoretical framework to explain the critical role of institutions in the development of resourcerich countries. The resource-curse (Dutch Disease) theory is rejected in explaining institutional underdevelopment of resource-rich countries. Dutch Disease theory suggests that resource-based industries and public sector crowd out human and capital development in other industries while the rent from natural resources cause corruption and inefficient institutions (Sachs and Warner 1995). In fact, some resource rich countries like Canada, Australia and Norway have inclusive (better) institutions, and have effectively managed their natural wealth and minimized the side effects of rent from natural resources such as corruption and non-resource private sector's demise. However, some other resource rich countries such as Libya and Venezuela have fallen into resource-curse trap not because of the rent from natural resources but because of the prevalence of bad institutions (Mehlum, Moene, and Torvik 2006). The authors do a regression analysis to see whether institutional quality or abundance of natural resources affect economic development. Their empirical analysis indicates that bad 
institutions produce a growth trap in resource rich countries. On the other hand, good institutions help resource rich countries to take the benefit of their rent revenue from natural resources (Mehlum, Moene, and Torvik 2006). The paper rejects Dutch Disease theory in explaining harmful effect of natural resource abundance on growth. Instead of Dutch Disease theory, the main culprit for lack of growth in some high natural resource countries are grabbing activities by entrepreneurs supported by bad institutions (Mehlum, Moene, and Torvik 2006).

Acemoglu, Johnson, and Robinson (2005) propose the SCT to explain the emergence of institutions. This theory suggests that the structure of the institutions is determined by the interests of a privileged group (people, monarchs, or elites) rather than economic efficiency or overall social welfare. North (1981) developed a theory explaining why agents who control the state, may act solely for their own purposes which can result in suboptimal economic outcomes. Acemoglu, Johnson, and Robinson (2005) suggest that political institutions determine de jure political power whereas distribution of economic resources determines de facto political power. These two sources of political power (de jure and de facto) shape economic institutions. Since current economic institutions determine the distribution of economic resources for the future, the incumbent political power holders (de jure and de facto in equilibrium) will try to devise the economic institutions in a way that would best serve their economic interests to further strengthen their political power in the next stage. ${ }^{2}$ Figure 2 summarizes these dynamics.

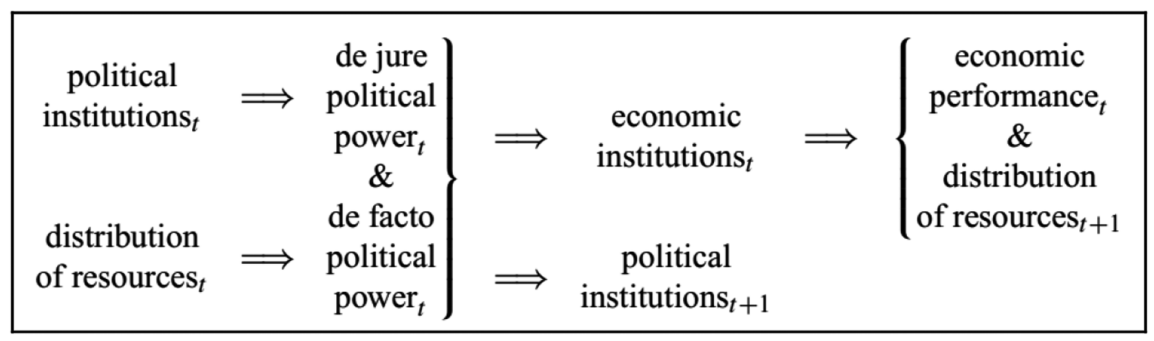

Figure 2: Dynamics between economic and political institutions based on the SCT, Acemoglu, Johnson, and Robinson (2005).

2 It is not always the case that both de jure and de facto political power are in the hands of the same group of elites. New economic opportunities may lead a politically powerless group (by de jure or law) to accumulate resources and gain de facto political power, which creates tension and imbalances in the current system (Acemoglu, Johnson, and Robinson 2005). If the new group can successfully mobilize its resources, it may gain de jure political power and hence secure its future economic interests through newly devised economic institutions. 
Based on the SCT, inclusive economic institutions have difficulty in emerging in economies with absolutist political institutions, since the change of economic power may lead to the change of political power. However, emergence of political and economic institutions may also be subject to the idiosyncratic social and economic features of a country.

\section{The Structure of Political Institutions in the GCC States}

The Gulf Cooperation Council (GCC) consists of 6 Arab countries: Bahrain, Kuwait, Oman, Saudi Arabia, Qatar and UAE, located in the Arabian Peninsula (Hvidt 2011). The political systems of these 6 countries are absolute monarchies with some varying degree regarding the role of parliament and the appointment of ministers. Most constitutions in GCC restrict the accession of rulers to the ruling family. For example, Article 1 section b of the Bahraini constitution states that the ruler should be the eldest son of the existing King. Similar statements can be found in Article 4 of Kuwait's Constitution, Article 5 of Oman's constitution, Article 5 section b of Saudi Arabia's constitution, and Article 8 of Qatar's constitution. For UAE, it is widely recognized that the next ruler for each emirate will be from the ruling family of that emirate. Kuwait is the only GCC country in which the accession of the ruler has to be approved by the parliament (Parolin 2006). The rule that governs the accession of rulers is the cornerstone of the political institutions of the tribal system that has prevailed in the GCC region for centuries (Crystal 1995; Heard-Bey 1997). In general, the political system allows the rulers to govern the countries without any counter balance of de jure power (Kshetri and Ajami 2008; Hvidt 2011). As a result, the media and press, for example, are subject to strict censorship in all GCC countries (Parolin 2006).

Despite the absolute political system, some of the GCC states have introduced partial democratic institutions. Specifically, Kuwait and Bahrain have functioning parliaments that vote on public policy and removal of ministers. The Emir of Kuwait retains the final decision rights on the appointment of the crown prince, the prime minister as well as the ministers for the interior, foreign affairs and defense ministries (Herb 2002; Kshetri and Ajami 2008). Qatar has an advisory council where two-third of its members are elected by the public and the remaining are selected by the Emir (Parolin 2006). While the Emir of Qatar has the full executive power of country affairs, the advisory council has the legislative power. The advisory council is responsible for drafting laws. If the 
Emir of Qatar refuses to approve the proposed law, the advisory council can pass the law with two-thirds of majority votes. The Emir must either promulgate the proposed law or suspend it under "compelling circumstances" (Parolin 2006). The Emir of Qatar can issue a decree to be approved by the advisory council. If two-thirds of the advisory council oppose to the proposed decree, the decree has to be amended or abandoned. The citizens of Bahrain, Kuwait and Qatar are thus entitled to limited legislative rights (Parolin 2006; Khodr 2014). In sum, with the democracy scores far below the world average, the EIU 2012 report classified all GCC states as countries having absolute political systems (Table 1).

Table 1: GCC democracy index.

\begin{tabular}{ll}
\hline Country/Year & $\mathbf{2 0 1 2}$ \\
\hline Bahrain & 2.53 \\
Kuwait & 3.78 \\
Oman & 3.26 \\
Qatar & 3.18 \\
Saudi Arabia & 1.71 \\
UAE & 2.58 \\
\hline
\end{tabular}

Source: EIU (2013).

Note: Democracy Index is scaled from 0 to 10 , with 10 being full democracy which allows fair elections, full political participation and the development of democracy supporting institutions such as free media. For 2012, Norway has the highest score of 9.93 while North Korea has the lowest score of 1.08 .

\section{Features of Economic Institutions in the GCC States}

Heavy direct involvement of state in local economy, tribalism, and sponsorship system for foreign residents are distinctive features of economic institutions in the GCC states. The GCC governments play a major role in domestic economies by fully controlling the extraction, utilization, and distribution of hydrocarbon resources (Beblawi 2011; Gray 2011). As shown in Table 2, most GCC governments have laws regarding the rights to monopolize the oil and gas sectors under state control (Davis 2006; Abdelal, Khan, and Khanna 2008; Sturm et al. 2008; Hvidt 2013, Yamada 2011; Flamos, Roupas, and Psarras 2013; Tsai 2013; Morakabati, Beavis, and Fletcher 2014). 
Table 2: Sectors under state control by law in the GCC economics.

\begin{tabular}{|c|c|c|}
\hline Country & Sectors under government control by law & Related laws and decrees \\
\hline Bahrain & & No explicit regulation \\
\hline Kuwait & $\begin{array}{l}\text { Oil and Gas Exploration, Production, } \\
\text { Distribution, Refinery and Selling of } \\
\text { Petroleum Products }\end{array}$ & $\begin{array}{l}\text { Article } 3 \text { of Law No } 6 \text { entrusts state- } \\
\text { owned Kuwait Petroleum Company for all } \\
\text { oil and gas related activities }\end{array}$ \\
\hline Oman & $\begin{array}{l}\text { Oil and Gas Exploration, Production, } \\
\text { Distribution, Refinery and Selling of } \\
\text { Petroleum Products }\end{array}$ & $\begin{array}{l}\text { No explicit regulation but all related firms } \\
\text { are controlled by the State }\end{array}$ \\
\hline Qatar & $\begin{array}{l}\text { Oil and Gas Exploration, Production, } \\
\text { Distribution, Refinery and Selling of } \\
\text { Petroleum Products }\end{array}$ & $\begin{array}{l}\text { Except Dolphin Pipeline, oil and gas } \\
\text { businesses in Qatar are operated by } \\
\text { state-owned Qatar Petroleum or its } \\
\text { partnership with foreign firms subject to } \\
\text { Amiri Decree. }\end{array}$ \\
\hline $\begin{array}{l}\text { Saudi } \\
\text { Arabia }\end{array}$ & $\begin{array}{l}\text { Oil and Gas Exploration, Production, } \\
\text { Distribution, Refinery and Selling of } \\
\text { Petroleum Products }\end{array}$ & $\begin{array}{l}\text { Although there is no explicit law, state- } \\
\text { owned Saudi Aramco has the sole owner } \\
\text { of concession for oil and gas extraction, } \\
\text { process, transportation and selling. }\end{array}$ \\
\hline UAE & $\begin{array}{l}\text { Oil and Gas Exploration, Production, } \\
\text { Distribution, Refinery and Selling of } \\
\text { Petroleum Products }\end{array}$ & $\begin{array}{l}\text { No federal level law in UAE regarding oil } \\
\text { and gas industry. Emirate of Abu Dhabi } \\
\text { with highest reserves of oil and gas has } \\
\text { enacted several laws to granting all rights } \\
\text { of oil and gas activities to state-owned } \\
\text { ADNOC. Similar practice can be found in } \\
\text { the emirate of Dubai. }\end{array}$ \\
\hline
\end{tabular}

GCC governments generally utilize the surplus from hydrocarbon revenues for overseas investment and the development of domestic economies through stateowned enterprises (Hvidt 2013). Table 3 shows the critical role of oil and gas revenue in the exports, government budget and Gross Domestic Product (GDP) of the GCC economies.

Table 3: Percentages of hydrocarbon revenue in export, state budget and GPD in 2011.

\begin{tabular}{lrrr}
\hline Country & \% of export earnings & \% of state budget & \% of GDP \\
\hline Bahrain & 69 & 86 & 24 \\
Kuwait & 90 & 93 & 45 \\
Oman & 65 & 77 & 41 \\
Qatar & 91 & 80 & 46 \\
Saudi Arabia & 85 & 85 & 50 \\
UAE & 69 & 77 & 32 \\
\hline
\end{tabular}

Source: Hvidt (2013). 
The Bahrain government has investments and state-owned companies operating in the financial, real estate, aluminum and tourism industries (Looney 1989; Mansfeld and Winckler 2008; Hertog 2010; Hvidt 2013). The Kuwait Investment Authority, a state-owned company, has major stakes in the sectors of tourism, finance, aviation, shipping, telecommunication and real estate (Sartawi 2012). Oman's government has majority ownership in telecommunication sectors and full ownership of Oman Air, the national airline company (Cordahi 2007; Dron 2014). Saudi Arabia's state owned conglomerate Saudi Basic Industries Corporation (SABIC) has subsidiaries in steel and fertilizer industries and it is rapidly expanding into other manufacturing sectors (Hertog 2010). The Saudi government has majority stake in Saudi Telecom Company, the biggest telecom company in the Arab world (Al-Adaileh and Al-Atawi 2011). The government of Qatar owns Qatar Telecom and Qatar Airlines. The Emirates of Abu Dhabi and Dubai in UAE have major stakes in the aluminum sector, air transportation, defense industry, shipping and port management, real estate (Sturm et al. 2008; El Beblawi 2010; Hooper et al. 2011). The Abu Dhabi government is the main investor of renewable energy industries in the GCC region through its Masdar Initiative (Mezher, Goldsmith, and Choucri 2011).

Tribalism is an important factor in determining the rulers' relationship with the population on both political and economic matters in the GCC countries (Heard-Bey 1997; Krane 2009; Gray 2011). Alshawi and Gardner (2013) state that "tribalism functions as a mechanism for asserting social power in the contemporary Qatari State, and is therefore an emblematic component of Qatari citizenship." (p. 46) This is quite similar in other GCC countries where the centuries-old relationships between the rulers and the tribes essentially guide the distribution of land, licenses as well as other economic benefits (Heard-Bey 1997; Abdelkarim 1999). Krane (2009) points out that the Dubai creek was expanded and upgraded with financial help of the rich local tribes such as Al-Ghurair, AlRostamanis, and Al-Futtaims. In return to their trust and support, Sheikh Rashid (the late ruler of Dubai between 1958 and 1990) rewarded them "with exclusive import licenses and business contracts" (Krane 2009, 70). A state's active engagement in the domestic economy along with tribalism may result in implicit entry barriers for the economy. A detailed study of merchant families in GCC states, their close connections to the ruling families and effects of tribalism in the economic activity have been discussed in detail by Hanieh (2015, chapter 5, particularly table 5.3 and appendix A of the book for family-conglomerates of each GCC state).

The sponsorship system is a system where migrant workers come to a GCC country under the sponsorship of a citizen or local firm and cannot quit their job 
and look for another opportunity despite some recent easing on this issue in some GCC states (Gardner 2011). Furthermore, foreign businesspeople need a local partner who should have a majority (51\%) stake in the company for certain economic sectors and markets in the GCC countries. Sponsorship makes the GCC economies even more rigid considering the significant and mostly dominant proportion of expatriates in the workforce of these countries (Table 4) (Forstenlechner and Rutledge 2011):

Table 4: Workforce share in the GCC economies.

\begin{tabular}{lrr}
\hline Country & & Workforce share \\
\cline { 2 - 3 } & National (\%) & Non-National (\%) \\
\hline Bahrain & 36.10 & 63.90 \\
Kuwait & 16.90 & 83.10 \\
Oman & 28.70 & 71.30 \\
Qatar & 5.70 & 94.30 \\
Saudi Arabia & 50.50 & 49.50 \\
UAE & 4.20 & 95.80 \\
\hline
\end{tabular}

Sponsorship and local partner requirement are designed to increase job chances for citizens and create for them extra revenue streams fitting into rentier paradigm prevalent in these countries. It is recognized that foreign direct investment (FDI) in non-oil businesses needed to replace falling oil revenues cannot be achieved easily in such an environment albeit many free zones and partial easing on these rules (Al Binali 2016).

For protection of private property, the constitutions of all GCC countries commit to protect private property rights and prohibit arbitrary confiscation except when the law sees necessary. The related laws can be found in Article 9 of Bahrain's constitution, Articles 17, 18, and 19 of Kuwait's Constitution, Article 11 of Oman's Constitution, Articles 18 and 19 of Saudi Arabia' constitution, Articles 27, 28, and 56 of Qatar' constitution, and articles 21 and 39 of UAE's constitution. Nevertheless, the lack of an independent judiciary system and of a free media may pose risk to legal enforcement and property rights protection. Robinson and Acemoglu (2012) explain in greater depth that absolute governments can resort to private property grabbing through excessive taxes or direct predation of private property. There are numerous historical examples of private property predation by an absolute authority stretching 
from European countries to Latin American and African dominions (Robinson and Acemoglu 2012).

\section{Development of Inclusive Economic Institutions in the GCC states}

To understand the development of inclusive economic institutions in the GCC states, this section proposes 4 indicators to measure economic inclusivity in the GCC region and reports the results.

\subsection{Measurements of Inclusive Economic Institutions}

The protection level of property rights, entry barriers, disruptive redistribution of wealth and corruption are used as the prominent metrics of the inclusivity of economic institutions (North 1990; Rodrik, Subramanian, and Trebbi 2004; Shirley 2005). The protection of property rights under a strong legal system has been empirically and theoretically shown to be the most significant factor that affects the difference of economic development (Keefer and Knack 1997; Clague et al. 1999; Rodrik, Subramanian, and Trebbi 2004; Acemoglu, Johnson, and Robinson 2005; Shirley 2005). There is a fundamental predicament regarding the strength of a state in protecting the rights of its citizens (Menard and Shirley 2005). A state should be powerful enough to guarantee contracts as a third party law enforcer but also be constrained from abusing its authority (Weingast 1995). This dilemma is particularly delicate in oligarchic or monarchic regimes (Bourguignon and Verdier 2000; Acemoglu 2003), where there exists a risk of expropriation or predation of private properties by the authority whose power is unchecked (Acemoglu, Johnson, and Robinson 2005). This constant threat of expropriation may either prevent private sectors from efficient investment or force them into underground economy which are generally detrimental to economic growth (Acemoglu 2003; North 2008).

The level of entry barrier to the market measures whether members of the society have equal opportunities accessing economic activities (Acemoglu and Robinson 2000; Buettner 2006; Acemoglu 2008). A society with higher level of entry barrier restricts the access to economic opportunities to a smaller group of privileged people. Entry barriers deter efficient investment in new technologies and 
services which in turn undermines economic growth potential (Acemoglu 2008). This results in a sub-optimal competitive market which is less efficient. In general, democratic societies tend to have lower entry barriers for economic activities whereas oligarchic societies tend to have high entry barriers as a means to protect the interests of the elite (Acemoglu 2008). Entry barriers can be created by increasing the cost to establish a business, lengthening and complicating the procedure for licensing of new businesses (Djankov et al. 2003). These are the instruments which the ruling elite may use to prevent a large fraction of society from participating in economic activity (Buettner 2006; Acemoglu 2008).

Disruptive wealth redistribution is a strong barrier of economic growth and the empowerment of the general public (Rodrik 1986; Acemoglu 2003; Bibi and Nabli 2009). Disruptive or inefficient wealth distribution through distortionary taxation policies is a strong impediment against long term growth as it deters private investment and causes outflow of capital (Romer 1975; Meltzer and Richards 1981; Rodrik 1986; Acemoglu 2003). Excessive and predatory taxation is the most common instrument used by the ruling authorities to distribute wealth in a way that may keep their economic power and secure future political privilege (North 1981; Coate and Morris 1995; Acemoglu 2003; Besley and Persson 2007).

Corruption is an unjust rent or benefit derived by the authority through abusing the official power at the expense of others (Aidt 2009; Miller and Kim 2013). Since the government and its bureaucracy is directly responsible for enforcement of contracts among private agents, the presence of corruption may severely distort protection of property rights (Acemoglu and Verdier 1998). Some examples of corruption include demanding bribery or blocking new firms from entering markets in favor of other firms or taking side of an agent unfairly in enforcing a contract by a bureaucrat (Acemoglu and Verdier 1998; Djankov et al. 2002). Corruption is highly associated with the lack of political accountability and weak property rights protection (Aidt 2009). Although corruption may have some greasing effect on doing business swiftly in an inefficient bureaucratic environment, it has a potential of causing misallocation of resources and discouraging new investment and firm creation (Myrdal 1968; DeSoto 1989). Corruption negatively affects the development of an economy as it deters efficient investment (Mauro 1995), directs public spending towards inefficient endeavors (Mauro 1998; Tanzi and Davoodi 1998), encourages rent seeking behavior among economic agents (Baldacci, Hillman, and Kojo 2004) and stimulates military spending (Gupta, Davoodi, and Tiongson 2000). Corruption usually hinders the attractiveness of a country to FDI 
(Hines 1995). Aidt (2009) suggests that corruption has negative long-term effects on sustainable development as it reduces genuine investment, which is a combination of human, knowledge, machinery and natural capital.

\subsection{GCC Performance on Economic Inclusivity}

We analyze the inclusivity of economic institutions of the GCC states using four indicators: legal rights and protection of private property, level of entry barriers, severity of disruptive wealth distribution, and level of corruption.

The "Legal Rights and Protection of Property Rights (LRPPR)" Index is taken from the Fraser Institute's "Economic Freedom of the World (EFW)" report in order to assess the perceived performance of property rights protection. The LRPPR index is an equally-weighted sum of 3 indicators, namely: (1) independence of judiciary system, (2) military involvement in rule of law and politics, (3) the level of contract enforcement and reliability of government and police in protecting property rights of individuals. Each of the indicators are compiled with data from the Global Competitiveness Report, World Economic Forum, International Monetary Fund and the World Bank. Table 5 shows the rating of each GCC country on the fairness and effectiveness of legal system and the level of property rights protection between 2010 and 2012:

Table 5: GCC ratings in legal system and protection of property rights.

\begin{tabular}{lccc}
\hline Country & \multicolumn{3}{c}{ Property rights score [Lowest, Highest]: } \\
\cline { 2 - 4 } & $\mathbf{2 0 1 0 2 , 8 . 9 ]}$ \\
\hline Bahrain & 7 & $\mathbf{2 0 1 1}$ & $\mathbf{2 0 1 2}$ \\
Kuwait & 7.1 & 6.8 & 6.3 \\
Oman & 7.6 & 7 & 7 \\
Qatar & 7.5 & 7.5 & 7.6 \\
Saudi Arabia & 7.7 & 7.9 & 8 \\
UAE & 7.3 & 7.5 & 7.4 \\
\hline
\end{tabular}

Note: Legal System and Protection of Property Right Index has been scaled from 0 to 10 while 10 is for the highest independence in legal system and protection of property rights. In 2012, Finland received the highest rating of 8.9 while Venezuela received the lowest rating of 2.2.

With the exception of Bahrain, all GCC countries rank among the global top 30 and are ahead of many democratic countries. Specifically, Qatar was ranked as the tenth best country in the world for 2012. Kuwait, Oman, Qatar, Saudi Arabia 
and UAE consistently derived higher-than-world-average rankings for their quality of legal system and the protection of property rights between 2010 and 2012. Bahrain's performance has been deteriorating as a result of political instability that stemmed primarily from its idiosyncratic social structure where the ruling family belongs to the minority sect of society (Nuruzzaman 2013). The performance for protection of private property in the GCC does not change significantly for each member country in year 2015 according to the index prepared by Property Rights Alliance (Table 6):

Table 6: GCC ratings in protection of property rights, 2015.

\begin{tabular}{lr}
\hline Country & $\begin{array}{r}\text { International property rights index 2015 } \\
\text { [Min, Max] [2.5, 8.3] }\end{array}$ \\
\hline Kuwait & 5.2 \\
Oman & 6.2 \\
Qatar & 7.5 \\
Saudi Arabia & 6 \\
UAE & 7.3 \\
\hline
\end{tabular}

Note: For the full report and detailed analysis: https://s3.amazonaws.com/ ipri2015/2015 + IPRI + final.pdf. In 2015, Finland received the highest rating as 8.3 while Myanmar received the lowest rating as 2.2.

For entry barrier to the markets, the EFW report publishes two relevant ratings: (1) Freedom to trade internationally (FEI) and (2) Regulation. Both ratings are scaled between 0 and 10 with 10 being the best performance. The FEI index measures the level of freedom and openness of an economy to international trade, a key component of economic activities under globalization (Gwartney, Hall and Lawson 2014). This index is an equally-weighted sum of indicators including taxation level of exports and imports, tariff rates, access to foreign currencies, restriction on foreign ownerships, and capital controls. The Regulation index measures whether a country has fair, transparent, and friendly regulations for business operations. It is calculated by weighting 15 different indicators within 3 sub categories, which are specifically (1) credit market regulations, (2) labor market regulations and (3) business regulations (see the Appendix for details). The "Regulation" rating ranks the level of ownership and independence of private banks, private sector's access to credit, employment procedure, and administrative requirements for getting business licenses, bureaucracy costs, and ease of starting new businesses. Table 7 shows the scores of GCC countries in these two indicators for years of 2010, 2011, and 2012: 
Table 7: GCC ratings in entry barrier related indexes.

\begin{tabular}{|c|c|c|c|c|c|c|}
\hline \multirow[t]{3}{*}{ Country } & \multirow{2}{*}{\multicolumn{3}{|c|}{$\frac{\text { Freedom to trade internationally }}{\text { [Lowest, Highest]: }[2.6,9.4]}$}} & \multirow{2}{*}{\multicolumn{3}{|c|}{$\begin{array}{r}\text { Regulation } \\
\text { [Lowest, Highest]: }[2.9,9.0]\end{array}$}} \\
\hline & & & & & & \\
\hline & 2010 & 2011 & 2012 & 2010 & 2011 & 2012 \\
\hline Bahrain & 8 & 7.9 & 7.7 & 8.3 & 8.7 & 8.5 \\
\hline Kuwait & 7.6 & 7.5 & 7.3 & 7.4 & 7.3 & 7.6 \\
\hline Oman & 8.1 & 8.1 & 8.3 & 8.3 & 8.1 & 8.2 \\
\hline Qatar & 7.8 & 7.8 & 7.8 & 7.6 & 7.2 & 8.6 \\
\hline Saudi Arabia & 7.2 & 7.3 & 6.1 & 7.9 & 7.8 & 8.1 \\
\hline UAE & 8.1 & 8.1 & 8.2 & 7.9 & 8 & 8.2 \\
\hline
\end{tabular}

Source: EFW Report (Gwartney, Hall and Lawson 2014).

Note: For the Freedom to Trade Internationally Index, Hong Kong received the highest rating of 9.4 while Iran received the lowest rating of 2.6 in 2012. For the Regulation Index, Hong Kong received the highest rating of 9.0 while Zimbabwe received the lowest rating of 3.9 also in 2012.

Performance of GCC countries vary on the level of freedom for international trade. Oman and UAE were generally ranked among the top 20 countries whereas Qatar and Bahrain were in top 50. Meanwhile, Kuwait and Saudi Arabia have become more restrictive to international trade over time. All GCC countries have improved or maintained regulation performance in the areas of credit market, labor market and ease of doing business. Specifically, Qatar was ranked as the $5^{\text {th }}$ best country, Bahrain ranked as $7^{\text {th }}$ and UAE ranked as $14^{\text {th }}$ worldwide for year of 2012.

Predatory taxation can be a key instrument for property predation and wealth redistribution (Acemoglu 2003). Different from the rest of the world, the GCC countries do not directly tax citizens due to rentier bargain prevailing in these states (Herb 2005; Hvidt 2011; Gray 2011). While Oman exercises corporate tax on firms, there is no value-added tax (VAT) or personal income tax in other GCC countries (Hertog 2013). The distortionary effect of tax on wealth distribution thus does not appear to be severe in GCC (Hvidt 2011). However, lack of taxation does not suggest that the GCC countries are effective in fair distribution of social welfare due to the influence of the tribal system. (Davidson 2009).

The corruption perception indexes are useful in showing the level of trust by people on proper functioning of political and economic institutions (Seligson 2002; Anderson and Tverdova 2003; Donchev and Ujhelyi 2014). The corruption index published by the Transparency International (TI) measures the perceived 
corruption of a specific country with surveys on households and firms (Aidt 2009). The index is scaled between 0 and 100 with 100 being the best performance. Table 8 shows the corruption index scores of GCC countries from the survey of Transparency International organization:

Table 8: GCC ratings in perceived corruption.

\begin{tabular}{lrcr}
\hline Country & \multicolumn{3}{c}{ Corruption score [Worst, Best]:[8, 92] } \\
\cline { 2 - 4 } & $\mathbf{2 0 1 2}$ & $\mathbf{2 0 1 3}$ & $\mathbf{2 0 1 4}$ \\
\hline Bahrain & 51 & 48 & 49 \\
Kuwait & 44 & 43 & 44 \\
Oman & 47 & 47 & 45 \\
Qatar & 68 & 68 & 69 \\
Saudi Arabia & 44 & 46 & 49 \\
UAE & 68 & 69 & 70 \\
\hline
\end{tabular}

Source: TI 2014.

Note: Denmark received the highest rating of 92 whereas North Korea and Somalia received the lowest rating of 8 for the Perceived Corruption Index in 2014.

Bahrain, Kuwait, Oman and Saudi Arabia have average scores regarding the perceived corruption level. Their performance has not changed considerably within the last three years. Only UAE and Qatar, ranked as the $25^{\text {th }}$ and $26^{\text {th }}$ least corrupted countries respectively, are perceived as less corrupted countries. GCC countries have a weaker performance in corruption index compared to property rights protection and entry barriers indexes. It is possible that rentier and patronage nature of GCC states may affect behavior of citizens. A pardoning and overlooking government to corruptive behavior of its citizens may partly play a role in relatively bad performance of the GCC states in corruption performance (Davidson 2009).

All the results above are similar to the assessment of World Economic Forum (WEF) regarding the economic competitiveness level of GCC countries. ${ }^{3}$ The WEF competitiveness index takes into account all of the indicators discussed in this paper while adding further dimensions such as healthcare and education, readiness for technological change, labor market efficiency, and sophistication of the business. ${ }^{4}$ Among 144 countries, GCC states are ranked in top 50 for competitiveness of their economies in year of 2015 (Table 9):

3 The WEF Competitiveness index for each country can be retrieved from: http://reports. weforum.org/global-competitiveness-report-2014-2015

4 In fact, Fraser's Institute uses some of the index scores developed by WEF in property rights protection and entry barriers to the market which can be seen in the appendix. 
Table 9: WEF competitiveness scores and ranks of GCC states in 2015.

\begin{tabular}{lrrr}
\hline Country & \multicolumn{2}{c}{ Competitiveness score } & Ranking \\
\cline { 2 - 2 } & [Least, Highest] [2.8, 5.7] & & [Worse, Best] [144, 1] \\
\hline Bahrain & 4.5 & 44 \\
Kuwait & 4.5 & 40 \\
Oman & 4.5 & 46 \\
Qatar & 5.2 & 16 \\
Saudi Arabia & 5.1 & 24 \\
UAE & 5.3 & 12 \\
\hline
\end{tabular}

Inclusive economic institutions have been developed at least partially in the GCC states despite the absolutist nature of these countries' political institutions. Country-wise, Qatar and UAE consistently scored high for legal system and protection of property rights and entry barriers (for years 2010, 2011, 2012) and perceived corruption (for years 2012, 2013, 2014). Bahrain has a worsening performance in almost all indicators although its performance is still higher than Saudi Arabia and Kuwait with the exception of property rights protection. Oman's institutional quality is good regarding legal system and protection of property rights and entry barriers but very poor in perceived corruption. Kuwait and Saudi Arabia are average for protection of property rights and entry barriers, and perform weakly in perceived corruption. No income or value-added tax suggest limited distortionary wealth extraction. The differences in these indexes may result in part from the difference in natural endowments per capita. Table 10 shows the oil export per capita of GCC countries in 2010 (Forstenlechner and Rutledge 2011; Beidas-Strom, Rasmussen, and Robinson 2011). ${ }^{5}$

High level of per capita oil and gas exports in Qatar and UAE may have allowed the rulers of these countries to accept the development of inclusive economic institutions in non-oil sectors at very limited cost to their economic and political power. While this argument may seem appealing, it is not consistent as Bahrain and Oman constantly outperform higher per capita oil and gas reserves Kuwait. The differences in performance of GCC countries for selected indicators may be related to the different legal systems in those countries. Saudi Arabia's constitution indicates that Islamic Law, known as "Sharia", is main reference for economic disputes as opposed to western style laws employed in

5 Table 6 is calculated by dividing the IMF petroleum export per capita data for 2010 (BeidasStrom, Rasmussen, and Robinson 2011), which uses residents of each country as the population, by the 2010 proportion of nationals in each country data from Forstenlechner and Rutledge (2011). 
Table 10: 2010 petroleum export per national capita in the GCC states.

\begin{tabular}{lr}
\hline Country & $\begin{array}{r}\text { Petroleum export per capita in 2010 } \\
\text { (Unit: Thousands of USD) }\end{array}$ \\
\hline Bahrain & 10.09 \\
Kuwait & 54.72 \\
Oman & 11.40 \\
Qatar & 274.15 \\
Saudi Arabia & 10.82 \\
UAE & 131.90 \\
\hline
\end{tabular}

other GCC countries. As the interpretation of "Sharia" is performed independently by each judge from the sacred text of Islam know as "Quran", inconsistencies are likely to exist across the country.

The indexes used in this paper are created through surveys with expatriates, business people and some citizens of each country by various international organizations such as IMF, World Bank, and Transparency International (Gwartney, Hall, and Lawson 2014; Donchev and Ujhelyi 2014). It is important to note that these ratings may either not fully reflect the current reality or may only reflect the view of those who participated in the surveys (Botero, Nelson, and Pratt 2011). After the discovery of fossil fuel resources, there has been a large number of migrant workers, in millions, from East Asian and African countries occupying low-paid jobs from security to housekeeping under the sponsorship system ("kafala" in Arabic) (Forstenlechner and Rutledge 2011; Dibbed 2014). This population depends on the local sponsors to engage in business related activity which significantly restrict their economic freedom. We believe most economic institution related indexes do not take into account these workers' condition and their perception about institutional quality in GCC states.

\section{Rationale for the Emergence of Inclusive Economic Institutions in the GCC States}

While the SCT suggests that an absolutist political system would deter the development of inclusive economic institutions, relevant ratings on economic inclusivity suggest that inclusive economic institutions have partly emerged in the GCC states. The following three schools of thought may provide the rationale 
for further emergence of inclusive economic institutions in GCC states: the market-preserving federalism theory (MPFT) developed by Weingast (1995), the RST for no taxation in non-democratic states (Mahdavy 1970; Beblawi 1987; Yates 1996; Herb 2005; Harrison 2010; Gray 2011; Hvidt 2011) and social efficient view theory known also as Political Coase Theorem (Acemoglu 2003).

Federalism or decentralization of political authority is an institutional form where the local economic activities are governed primarily by local authorities instead of the central government (Weingast 1995). The presence of marketpreserving federalism in an absolutist political system may partially alleviate the risk of private property expropriation and mitigate the effects of entry barriers introduced by one of the local authorities (Riker 1964). Weingast (1995) identifies seven conditions for an economy to be called a market-preserving federalism: (1) the existence of a well-defined hierarchy between local and central governments, (2) autonomy of the local governments in governing local economic affairs, (3) existence of law to guarantee the autonomy of the local governments, (4) legislative rights of the local governments on local economic affairs, (5) mobility of goods, services and people across the local borders, (6) explicit revenue sharing rule between the central and the local governments, and (7) well-defined allocation of authority between the hierarchy of governments (Rubinfeld 1997). China's fast growing economy in the last two decades, for example, can be attributed to the sharing of power between the central and the local governments as well as the freedom local governments enjoy in initiating economic activities (Montinola, Qian, and Weingast 1995). There are three empirical analyses on the Chinese reform towards decentralization and economic empowerment of local authorities. While the first two empirical studies claim opposite of the MPFT, the last one refutes those claims and points out a positive and significant relationship between decentralization and economic performance. Zhang and Zhou (1998) have found out that fiscal decentralization affects provincial growth negatively and significantly. They use ratio of provincial government spending to central government spending as a measurement for degree of fiscal decentralization. Huang (1996) studies the effect of "bureaucratic integration" among provincial and central government officials. It has been found out that higher integration between provincial and central governments, i. e. less decentralization or stronger central government, resulted in better inflation control and macroeconomic performance in China. The primary reason was higher integration and stronger central authority has curbed the excessive and inefficient provincial fixed investments. Jin, Qian and Weingast (2005) show that decentralization has a positive and significant effect on economic development across China's provinces once economy-wide cyclical affects are eliminated. They point out that Zhang and Zhou's results (1998) were opposite to their 
findings due to their failure of filtering out economy-wide cyclical affects. The authors thus argue that decentralization or market preserving federalism may substitute for democracy, rule of law or separation of powers in implementing effective and market friendly economic system.

Despite the difficulty of achieving market-preserving federalism (Rodden and Rose-Ackerman 1997), GCC countries have moved towards free trans-boundary movement of labor, capital, services and products with the signature of the Economic Agreement of the GCC member states (or the "Economic Agreement”) in 2001 (Sahib and Kari 2012). Article 1 of the Economic Agreement states that there should be one common external tariff with non-GCC countries. The member countries will introduce common customs regulations and procedures and allow free movement of goods and service within the GCC. Article 3 states that any GCC citizen has equal rights regarding movement of labor and capital, residence, firm and real estate ownerships, tax treatment and social services. Article 4 requires all GCC states to unify laws and regulations regarding investment, equal treatment of investments by GCC citizens, integrate financial regulations and policies, and unification of product standards and specifications. Article 27 lays out the procedures to settle disputes on intra-GCC trade and economic activities with the establishment of a GCC Commercial Arbitration Center. A specialized judicial commission will be established in case the Arbitration Center fails to settle the dispute. The Economic Agreement further encourages member states to integrate oil and gas policies, coordinate international aid, create a single monetary and fiscal policies without any binding constraint.

In 2005, customs with non-GCC countries were unified under a single external tariff system. A common market was declared in 2008 for freedom of economic activities among GCC countries (Beblawi 2011; Hvidt 2013). GCC countries retain full sovereignty inside their boundaries and authority on all economic decisions (fiscal or monetary policies) other than specified by GCC and international agreements (Legrenzi 2011). Since the Economic Agreement has no binding article on the local authority of member countries other than long term objectives, the regional integration essentially create a system that meets the conditions for market preserving federalism. Meanwhile, UAE's consistently high performance in selected economic indicators can partially be attributed to its federal structure where each emirate has the autonomy over local affairs (Van Der Meulen 1997; Foley 1999).

The RST argues that it is very difficult to tax citizens in a rentier state where natural resources dominate the economy and large section of the population has no political power (Ross 2001; Herb 2003 \& 2005). A rentier state is where few of the population involves directly in creation of wealth while the rest of society is 
involved in distribution and utilization of the wealth (Beblawi 1987; Herb 2003; Hvidt 2011). The "rentier social contract" (rentier bargain, ruling bargain) is one where the rentier government distributes accrued wealth to the society through services, social benefit programs and favorable governmental jobs in exchange for the society's refrain from obtaining political power (Wiktorowicz 1999; Herb 2005; Hvidt 2013). The wealth is usually accrued through extraction and selling of valuable natural resources under full control of the government (Beblawi, 1987; Hvidt, 2011). The major task of a rentier state is therefore the distribution of wealth as opposed to extracting rent from the population.

GCC countries are classified as rentier states (Beblawi 1987; Harrison 2010; Hvidt 2011).Thanks to very large hydrocarbon reserves; there is little or no tax in the GCC states (Herb 2002; Niblock and Malik 2007; Spiess 2008; Saif 2009; Hvidt 2013; Apergis and Payne 2014). While taxation needs not necessarily lead to private property predation or distortionary wealth distribution (Besley and Persson 2007), predatory taxation is one of the major instruments for a corruptive and extractive government to predate property and create unfair wealth redistribution (North 1981; Coate and Morris 1995; Acemoglu 2003, Acemoglu, Johnson, and Robinson 2005). There are two cases for limited or zero taxation in GCC for the future: (1) failure of previous attempts in taxing expatriates and citizens in Bahrain, Kuwait and Saudi Arabia due to social resistance and the fear of losing expatriate workforce and investors (Janardhan 2002; Harrison 2010), and (2) the fear of rising demand for policy accountability that naturally come along with the introduction of taxation (Hertog 2015). As a result, taxation, especially income tax, is not easy to be implemented in the GCC countries. In fact, even countries with decreasing hydrocarbon revenue in this region have no intention to impose any form of tax on their citizens (Davidson 2008, chapter 5 \& 2009, chapter 6).

Federalism and rentier system of the GCC countries may not prevent the rulers from predating private property particularly in difficult times when no rents are available. The PCT states that socially efficient economic institutions (i. e. inclusive economic institutions) can be achieved regardless of the type of political institutions since this will make everyone better off (Pareto superiority) (Acemoglu, Johnson, and Robinson 2005). Therefore political power groups may agree to the inclusive economic institutions provided that an effective transfer mechanism is in place to channel the accrued benefits from inclusivity towards these groups. The key concern in this proposition is how politically powerful groups will stick to their commitment of not grabbing everything ex-post since there is no third party to prevent the breaching of the agreement. This is known as the commitment problem and the major obstacle in establishing inclusive economic institutions under absolute political systems. Nonetheless the 
commitment problem in an absolutist political system can be restrained when the ruler is better off by not predating all the private output which would force investors to leave the country or take illegal economic action (Acemoglu 2003). For the commitment problem to be overcome, the ruler and the citizens should realize simultaneous benefit from inclusive economic institutions which require ruler's confidence for a very long stay in power and efficient transfer mechanism to share the benefits. The willingness for the rulers to respect property rights and fair distributions of welfare can be achieved when they don't perceive any threat to their political authority (Acemoglu 2003). ${ }^{6}$

The current political structure in GCC states give the rulers relatively longer perception of staying in power, which is a must for inclusive economic institutions to exist in such a political system (Acemoglu 2003). In the GCC, the current political system has been in place for more than two centuries with a close and strong relationship between the ruler and the citizens due to tribal culture (Peterson 2001). Even from the citizens' perspective, it may be desirable to retain the existing regime if it is costly to change the political system (Acemoglu 2003). The recent chaotic situations in Egypt, Syria and Yemen due to political upheavals have suggested that the cost of regime change in this region could be very high (Nuruzzaman 2013). Meanwhile, the GCC countries have been expanding state controlled aviation, shipping and the manufacturing industries as well as establishing free trade zones and economic cities to diversify revenue sources of the government (Krane 2009). Additional to oil and gas revenues, the revenue generated form these initiatives are mostly controlled by the governments and contribute to building strong security apparatuses (Davidson 2009). Strong state involvement in certain economic sectors may indirectly benefit the rulers from a growing and prospering economic activity and hence establish an efficient transfer mechanism required for inclusive economic institutions in such states.

\footnotetext{
6 Acemoglu (2003) develops a model to show "the economic rationale for socially and politically powerful groups to extract resources from the rest of the population in inefficient ways and to set up bad institutions." However, the model indicates that rulers can commit to an initial tax level and respect to property right to incentivize citizens taking legal (formal) economic activity rather than underground (informal) and relatively less efficient economic activities without any change in current absolute political system. The model also shows that distribution of extra economic benefit (output) from legal economic activity between ruler and citizens depend on the relative bargaining power of each side which can be expressed as a Nash bargaining procedure. Commitment of fair future taxes by ruler and no demand of political power by citizens, inclusive economic institutions can emerge in absolutist political systems as suggested by the PCT (Acemoglu 2003).
} 


\section{Conclusion and Discussions}

The effect of institutions on economic performance has been shown to be significant as compared to the effects from other factors such as climate, geographical location, or international trade (North 1990; Keefer and Knack 1995, 1997; Clague etal. 1999; Rodrik, Subramanian, and Trebbi 2004; Acemoglu, Johnson, and Robinson 2005, Shirley 2005). Inclusive economic institutions facilitate market-based transactions, enforce contracts and protect property rights. While inclusive economic institutions are desirable for economic development, the SCT proposes that absolute monarchies will not tolerate or adapt the development of inclusive economic institutions as a change of economic power may lead to a change of political power (Acemoglu, Johnson, and Robinson 2005). This paper analyzes the development of inclusive economic institutions in the Gulf Cooperation Council (GCC) countries where absolute monarchies dominate. We examine four economic inclusivity related indicators, including legal system and protection level of property rights, entry barriers, disruptive redistribution of wealth and corruption, and found that GCC countries have achieved above or around global rankings in the selected measures.

This result shows the emergence of inclusive economic institutions in the GCC countries where absolutist political institutions dominate. While the performance of the GCC countries in economic inclusivity has been improving, there exists an obvious variation across countries and the reason is not clear. It is possible that high performances of Qatar and UAE in all variables can be attributed to their high oil reserves per capita (Fasano and Iqbal 2003; de Boer and Turner 2007) and hence relative strong comparative advantage in pursuing inclusive economic institutions. This observation, however, cannot be generalized as less oil reserve per capita Oman have outperformed both higher oil per capita Kuwait in most indicators. Bahrain's worsening performance for the indicators of legal system and protection of property rights and freedom to trade internationally can be attributed to the political instability of the country (Nuruzzaman 2013).

GCC states have established many state owned enterprises (SOEs) as part of the effort to diversify the economy (Hvidt 2013). While the SOEs of the GCC states tend to perform better than those in other developing countries (Hertog 2010) and guide the country towards high-value added sectors (Cherif and Hasanov 2014), it is likely that the increasing state involvement in economy, resilient tribal structure of the society and current sponsorship system have introduced implicit entry barriers to economic participation. A future study may help to verify the interactive effects of heavy state involvement and tribalism on the evolution of political and economic institutions in the GCC. The sponsorship 
("kafala" in Arabic) requirement for foreign workers exacerbate these effect further and make the economy more rigid as a large portion of workers are partly or full restrained from opening up their own business or easily switch into another business. This problem is more acute especially for low-paid workers such as private security workers, house maids and construction workers who constitute the majority of the work force in those countries. These three structural factors may become the pillars of market failure in GCC states, a dangerous outcome where resources (human and capital) are widely underutilized. Once oil revenues fall, as happening nowadays, and GCC governments run out of their reserves, there is a very high risk of facing a rapid economic decline.

The indexes used in this study should be treated with concern since they usually reflect viewpoints of white collar workers, citizens and managers generally working in government owned, international or large local companies. We believe that creators of those indexes have probably interviewed people associated with oil and gas related industries for GCC states. This has potential of positive bias towards the performance of these countries since workers or residents associated with low paid sectors are excluded. A future study is necessary to analyze dynamics of government's accountability in GCC countries as accountability is becoming increasingly important in measuring quality of legal rights and protection of property (Schedler 1999; Curtin and Nollkaemper 2005). World Justice Project's Rule of Law index particularly focusing on the accountability could give another rating to compare with the one currently used in this study but the former index has no rating on GCC countries except for UAE (Agrast, Botero, and Ponce 2010). (Cherif and Hasanov 2014) and Cammett et al. (2015) point out similar performance levels with the indexes used in this paper such as for property rights protection (rule of law), economic freedom and ease of doing business and corruption in government.

Three theories provide the rationale for the emergence of inclusive economic institutions in the absolute monarchies of the Gulf: (1) Intensifying economic integration among GCC countries has the potential to increase economic inclusiveness as claimed by the MPFT. (2) The focus of the rulers of the GCC countries as rentier states in wealth distribution versus rent extraction may have alleviated the predation of private properties and the introduction of distortionary taxation known as the RST. (3) Incentive to sustain long term economic gain and mitigate the emergence of underground economy following the PCT. Since the current political system has existed for centuries in the GCC region and the ruling kings, sultans or emirs normally stay in power for life before passing the throne to one of the relatives, the ruling elites tend to plan for long horizons which is a condition for the PCT to work.

This research suggests that the emergence of inclusive economic institutions in the GCC region may not be related only to the SCT, but also the MPFT, RST, 
and the PCT. It is then interesting to study the future emergence path of economic and political institutions in the GCC countries. Institutions are path dependent and deeply affected by cultural and social traits of a country (North 1990; Boettke, Coyne, and Leeson 2008). Kshetri and Ajami (2008) point out political and bureaucratic interferences in businesses Schlumberger (2000), future role of oil in GCC economies (Facchini 2013), presence of western-educated leaders and technocrats, overall readiness of society and its ability to adapt institutional change (Bush 1994; Campbell 2004) and role of religion (Kuran 1995; Facchini 2010 \& 2013) may all have great potential to affect the direction and process of the evolution of institutions in the GCC countries. Cherif and Hasanov (2014) discuss in greater length how to tackle citizens' rentier mantra in GCC states by the respective governments.

This paper investigated the critical issue of emergence of inclusive economic institutions in GCC states based on the current political system. The recent collapse in oil prices and widening budget deficits of GCC states make an urgent call for a more inclusive and diversified economy (Al-Khatteeb 2015). We have shown that it is not impossible for inclusive economic institutions to emerge under the existent absolute political system of the GCC despite the associated daunting challenges.

\section{Important Abbreviations}

The social conflict theory: the SCT

The market-preserving federalism theory: the MPFT

The rentier state theory: the RST

The political Coase theory: the PCT

\section{Appendix}

Fraser Institute's report "Economic Freedom of the World, 2014" provides sub indicators for each main indicator and their sources.

\section{Indicators Used in Rating of "Legal System and Protection of Property Rights"}

The "Economic Freedom of the World, 2014" report equally averages 9 indicators for rating of a country's performance of legal system and protection of property rights. These indicators are collected from the following resources as 
shown in brackets: "Judicial independence" (World Economic Forum, Global Competitiveness Report), "Impartial courts" (World Economic Forum, Global Competitiveness Report), "Protection of property rights" (World Economic Forum, Global Competitiveness Report), "Military interference in rule of law and politics" (PRS Group, International Country Risk Guide; World Bank, Worldwide Governance Indicators), "Integrity of the legal system" (PRS Group, International Country Risk Guide), "Legal enforcement of contracts" (World Bank, Doing Business), "Regulatory restrictions on the sale of real property" (World Bank, Doing Business), "Reliability of police, and Business costs of crime" (World Economic Forum, Global Competitiveness Report).

\section{Indicators Used in Rating of "Freedom to Trade Internationally"}

In total, 9 indicators are selected in rating the level of freedom in trading internationally with their sources are given in brackets: "Revenue from trade taxes as \% of trade sector" (International Monetary Fund, Government Finance Statistics Yearbook; International Monetary Fund, International Financial Statistics), "Mean tariff rate" (World Trade Organization, World Tariff Profiles), "Standard deviation of tariff rates" (World Trade Organization, World Tariff Profiles), "Non-tariff trade barriers" (World Economic Forum, Global Competitiveness Report), "Compliance costs of importing and exporting" (World Bank, Doing Business), "Black market exchange rates” (MRI Bankers' Guide to Foreign Currency), "Foreign ownership/investment restrictions" (World Economic Forum, Global Competitiveness Report), "Capital controls" (International Monetary Fund, Annual Report on Exchange Arrangements and Exchange Restrictions), Freedom of foreigners to visit (Lawson and Lemke 2012).

\section{Indicators Used in Rating of "Regulation"}

15 indicators are used for rating the performance regulations in a country regarding business practices with their sources are given in brackets: "Ownership of banks" (World Bank, Bank Regulation and Supervision Survey; Barth, Caprio, and Levine 2008), "Private sector credit" (World Bank, World Development Indicators; World Economic Forum, Global Competitiveness Report; International Monetary Fund, International Financial Statistics), "Interest rate controls/negative real interest rates" (World Bank, World Development Indicators; International Monetary Fund, International Financial 
Statistics), "Hiring regulations and minimum wage" (World Bank, Doing Business), "Hiring and firing regulations" (World Economic Forum, Global Competitiveness Report), “Centralized collective bargaining” (World Economic Forum, Global Competitiveness Report), "Hours regulations" (World Bank, Doing Business), "Mandated cost of worker dismissal” (World Bank, Doing Business), "Conscription" (International Institute for Strategic Studies, The Military Balance; War Resisters International, World Survey of Conscription and Conscientious Objection to Military Service; additional online sources used as necessary), “Administrative requirements” (World Economic Forum, Global Competitiveness Report), "Bureaucracy costs” (World Economic Forum, Global Competitiveness Report), "Starting a business” (World Economic Forum, Global Competitiveness Report), “Licensing restrictions” (World Bank, Doing Business), "Cost of tax compliance” (World Bank, Doing Business).

\section{References}

Abdelal, R., A. Khan, and T. Khanna. 2008. "Where Oil-Rich Nations Are Placing Their Bets." Harvard Business Review 86 (9):119-28.

Abdelkarim, A., ed. 1999. Change and Development in the Gulf. Basingstoke: Macmillan.

Acemoglu, D. 2003. "Why Not a Political Coase Theorem? Social Conflict, Commitment, and Politics." Journal of Comparative Economics 31 (4):620-52.

Acemoglu, D. 2008. "Oligarchic Versus Democratic Societies." Journal of the European Economic Association 6 (1):1-44.

Acemoglu, D., S. Johnson, and J. A. Robinson. 2000. "The Colonial Origins of Comparative Development: An Empirical Investigation (No. w7771).” National Bureau of Economic Research.

Acemoglu, D., S. Johnson, and J. A. Robinson. 2005. "Institutions as a Fundamental Cause of Long-Run Growth." Handbook of Economic Growth 1:385-472.

Acemoglu, D., and J. A. Robinson. 2000. "Political Losers as a Barrier to Economic Development." The American Economic Review 90 (2):126-30.

Acemoglu, D., and T. Verdier. 1998. "Property Rights, Corruption and the Allocation of Talent: A General Equilibrium Approach.” The Economic Journal 108 (450):1381-403.

Agrast, M. D., J. C. Botero, and A. Ponce. 2010. "Rule of Law Index 2010.” Technical report, World Justice Project, Washington, DC. http://worldjusticeproject.org

Aidt, T. S. 2009. “Corruption, Institutions, and Economic Development." Oxford Review of Economic Policy 25 (2):271-91.

Al-Adaileh, R. M., and M. S. Al-Atawi. 2011. "Organizational Culture Impact on Knowledge Exchange: Saudi Telecom Context." Journal of Knowledge Management 15 (2):212-30.

Al Binali, S. 2016. "Foreign Investment Could Make Low-Oil Belt Tightening Easier To Bear." The National.

Albouy, D. 2004. "The Colonial Origins of Comparative Development: A Reexamination Based on Improved Settler Mortality Data." Department of Economics, University of CaliforniaBerkeley, Working Paper. 
Al-Khatteeb, L. 2015. “Gulf Oil Economies Must Wake Up or Face Decades of Decline.” http:// www.brookings.edu/research/opinions/2015/08/14-gulf-oil-economies-alkhatteeb

Alshawi, A. H., and A. Gardner. 2013. "Tribalism, Identity and Citizenship in Contemporary Qatar." Anthropology of the Middle East 8 (2):46-59.

Anderson, C. J., and Y. V. Tverdova. 2003. "Corruption, Political Allegiances, and Attitudes Toward Government in Contemporary Democracies." American Journal of Political Science 47 (1):91-109.

Apergis, N., and J. E. Payne. 2014. "The Oil Curse, Institutional Quality, and Growth in MENA Countries: Evidence From Time-Varying Cointegration.” Energy Economics 46:1-9.

Arezki, R., and O. Blanchard. 2014. "Seven Questions about the Recent Oil Price Slump." IMF Direct Blog: http://blog-imfdirect.imf.org/2014/12/22/seven-questions-about-the-recentoil-priceslump.

Baldacci, E., A. L. Hillman, and N. C. Kojo. 2004. "Growth, Governance, and Fiscal Policy Transmission Channels in Low-Income Countries." European Journal of Political Economy 20 (3):517-49.

Barth, J. R., G. Caprio, and R. Levine. 2008. Rethinking Bank Regulation. Till Angels Govern. Cambridge University Press.

Beblawi, H. 1987. “The Rentier State in the Arab World." Arab Studies Quarterly 9 (4):383-98.

Beblawi, H. E. 2010. Gulf industrialization in perspective. Industrialization in the Gulf: A Socioeconomic Revolution, 185.

Beblawi, H. E. 2011. "Gulf Industrialization in Perspective." In Industrialization in the Gulf: A Socioeconomic Revolution, edited by J. -F. Seznec and M. Kirk, 185-97. London: Center for Contemporary Arab Studies, Georgetown University/Routledge.

Beidas-Strom, S., T. N. Rasmussen, and D. O. Robinson. 2011. Gulf Cooperation Council Countries (GCC): Enhancing Economic Outcomes in an Uncertain Global Economy. International Monetary Fund.

Besley, T., and T. Persson. 2007. "The Origins of State Capacity: Property Rights, Taxation, and Politics (No. w13028).” National Bureau of Economic Research.

Bibi, S., and M. K. Nabli. 2009. "Income Inequality in the Arab Region: Data and Measurement, Patterns and Trends." Middle East Development Journal 1 (2):275-314.

Bloom, D. E., J. D. Sachs, P. Collier, and C. Udry. 1998. "Geography, Demography, and Economic Growth in Africa." Brookings papers on economic activity, 207-295.

Boettke, P. J., C. J. Coyne, and P. T. Leeson. 2008. "Institutional Stickiness and the New Development Economics." American Journal of Economics and Sociology 67 (2):331-58.

Botero, J. C., R. L. Nelson, and C. Pratt. 2011. “Indices and Indicators of Justice, Governance, and the Rule of Law: An Overview." Hague Journal on the Rule of Law 3 (02):153-69.

Bourguignon, F., and T. Verdier. 2000. "Oligarchy, Democracy, Inequality and Growth." Journal of Development Economics 62 (2):285-313.

Buettner, B. 2006. “Entry Barriers and Growth.” Economics Letters 93 (1):150-5.

Bush, P. D. 1994. "The Pragmatic Instrumentalist Perspective on the Theory of Institutional Change." Journal of Economic Issues 28 (2):647-57.

Cammett, M., I. Diwan, A. Richards, and J. Waterbury. 2015. A Political Economy of the Middle East. Boulder, Colorado: Westview Press.

Campbell, J. L. 2004. Institutional Change and Globalization. Princeton University Press.

Cherif, R., and F. Hasanov. 2014. "Soaring of the Gulf Falcons: Diversification in the GCC Oil Exporters in Seven Propositions (No. 14-177)." International Monetary Fund. 
Chernozhukov, V., and C. Hansen. 2008. "The Reduced Form: A Simple Approach to Inference with Weak Instruments.” Economics Letters 100 (1):68-71.

Clague, C., P. Keefer, S. Knack, and M. Olson. 1999. "Contract-Intensive Money: Contract Enforcement, Property Rights, and Economic Performance.” Journal of Economic Growth 4 (2):185-211.

Coate, S., and S. Morris. 1995. "On the Form of Transfers to Special Interests." Journal of Political Economy, 1210-35.

Cordahi, J. 2007. “Emirates Telecom Says Eyeing Omantel Stake”. Reuters (Thomson Reuters). Retrieved March 5, 2009.

Crystal, J. 1995. Oil and Politics in the Gulf: Rulers and Merchants in Kuwait and Qatar (Vol.24). Cambridge University Press.

Curtin, D., and A. Nollkaemper. 2005. "Conceptualizing Accountability in International and European Law." Netherlands Yearbook of International Law 36 (01):3-20.

Davidson, C. M. 2008. Dubai: The Vulnerability of Success. New York: Columbia University Press.

Davidson, C. M. 2009. Abu Dhabi: Oil and Beyond. New York, NY: Columbia University Press.

Davis, M. 2006. "Fear and Money in Dubai." New Left Review 41:47.

Davis, K. E. 2010. "Institutions and Economic Performance: An Introduction to the Literature." In Institutions and Economic Performance, edited by K. E. Davis, 9-51. Edward Elgar.

de Boer, K., and J. M. Turner. 2007. "Beyond Oil: Reappraising the Gulf States." McKinsey Quarterly 1:112.

DeSoto, H. 1989. The Other Path. The Invisible Revolution in the Third World. Perennial Library: New York.

Dibeh, G. 2014. "The Political Economy of Monetary Policy in Resource-Rich Arab Economies." Working Paper No. 896. Economic Research Forum.

Djankov, S., E. Glaeser, R. La Porta, F. Lopez-de-Silanes, and A. Shleifer. 2003. "The New Comparative Economics." Journal of Comparative Economics 31 (4):595-619.

Donchev, D., and G. Ujhelyi. 2014. "What Do Corruption Indices Measure?" Economics \& Politics 26 (2):309-31.

Dron, A. 2014. “Oman Air appoints new CEO”. Air Transport World. Archived 10 August 2014 at the Wayback Machine

EIU, 2013. "Democracy Index 2012: Democracy and its discontents". Report from The Economist Intelligence Unit, 1-55.

Facchini, F. 2010. "Religion, Law and Development: Islam and Christianity-Why Is It in Occident and Not in the Orient That Man Invented the Institutions of Freedom?" European Journal of Law and Economics 29 (1):103-29.

Facchini, F. 2013. "Economic Freedom in Muslim Countries: An Explanation Using the Theory of Institutional Path Dependency." European Journal of Law and Economics 36 (1):139-67.

Fasano, U., and Z. Iqbal. 2003. GCC Countries: From Oil Dependence to Diversification. International Monetary Fund.

Flamos, A., C. V. Roupas, and J. Psarras. 2013. "GCC Economies Diversification: Still a Myth?" Energy Sources, Part B: Economics, Planning, and Policy 8 (4):360-8.

Foley, S. 1999. "The UAE: Political Issues and Security Dilemmas." Middle East 3 (1):26.

Forstenlechner, I., and E. J. Rutledge. 2011. "The GCC's "Demographic Imbalance": Perceptions, Realities and Policy Options." Middle East Policy 18 (4):25-43.

Gardner, A. M. 2011. "Gulf Migration and the Family." Journal of Arabian Studies 1 (1):3-25. Goodstein, D., and O. O. Gas. 2004. "The End of the Age of Oil." Caltech Ews 38 (2). 
Gray, M. 2011. A Theory of "Late Rentierism" in the Arab States of the Gulf. Center for International and Regional Studies, Georgetown University, School of Foreign Service in Qatar.

Greif, A. 2008. "Commitment, Coercion, and Markets: The Nature and Dynamics of Institutions Supporting Exchange." In Handbook of New Institutional Economics, 727-86. Springer Berlin Heidelberg: Springer US.

Groenewegen, J., and M. van der Steen. 2007. "The Evolutionary Policy Maker." Journal of Economic Issues 41 (2):351-8.

Gupta, S., H. R. Davoodi, and E. Tiongson. 2000. Corruption and the Provision of Health Care and Education Services (No. 2000-2116). International Monetary Fund.

Gwartney, J., J. C. Hall, and R. A. Lawson. 2014. "Economic Freedom of the World: 2014 Annual Report Published Fraser Institute." www.freetheworld.com or www.fraserinstitute.org.

Hanieh, A. 2015. Capitalism and Class in the Gulf Arab States. Palgrave Macmillan.

Harrison, M. 2010. Taxation and the GCC States. Gulf One Lancaster Centre for Economic Research Report. Lancashire: Lancaster University Management School.

Heard-Bey, F. 1997. "The Tribal Society of the UAE and Its Traditional Economy." Perspectives on the United Arab Emirates, 254-72.

Herb, M. 2002. "Emirs and Parliaments in the Gulf." Journal of Democracy 13 (4):41-7.

Herb, M. 2003. "Taxation and Representation." Studies in Comparative International Development 38 (3):3-31.

Herb, M. 2005. "No Representation Without Taxation? Rents, Development, and Democracy." Comparative Politics, 297-316.

Hertog, S. 2010. "Defying the Resource Curse: Explaining Successful State-Owned Enterprises in Rentier States." World Politics 62 (2):261-301.

Hertog, S. 2013. "The Private Sector and Reform in the Gulf Cooperation Council (No. 54398)." London School of Economics and Political Science, LSE Library.

Hertog, S. 2015. "Oil Prices: Eventually the Gulf States Will Run Out Of Power.” The Conversation.

Hines, J. R. 1995. “Forbidden Payment: Foreign Bribery and American Business After 1977 (No. w5266)." National Bureau of Economic Research.

Hooper, P., S. Walker, C. Moore, and Z. Al Zubaidi. 2011. "The Development of the Gulf Region's Air Transport Networks-the First Century." Journal of Air Transport Management 17 (6):325-32.

Howell, L. D. 2011. International Country Risk Guide Methodology. East Syracuse, NY: PRS Group.

Huang, Y. 1996. "Central-Local Relations in China During the Reform Era: The Economic and Institutional Dimensions." World Development 24 (4):655-72.

Hvidt, M. 2011. "Economic and Institutional Reforms in the Arab Gulf Countries." The Middle East Journal 65 (1):85-102.

Hvidt, M. 2013. "Economic Diversification in GCC Countries: Past Record and Future Trends." Janardhan, N. 2002. "Saudi Income Tax Plan Scares Gulf Expatriates," Inter Press Service, 10 May 2002.

Jin, H., Y. Qian, and B. R. Weingast. 2005. "Regional Decentralization and Fiscal Incentives: Federalism, Chinese Style." Journal of Public Economics 89 (9):1719-42.

Khodr, H. 2014. "A Preliminary Comparative Study of Policy Making in Two GCC CountriesQatar and Kuwait: Processes, Politics, and Participants." Politics \& Policy 42 (2):271-310. 
Knack, S., and P. Keefer. 1995. "Institutions and Economic Performance: Cross-Country Tests Using Alternative Institutional Measures.” Economics \& Politics 7 (3):207-27.

Krane, J. 2009. City of Gold: Dubai and the Dream of Capitalism. New York. US: Macmillan. Kshetri, N., and R. Ajami. 2008. "Institutional Reforms in the Gulf Cooperation Council Economies: A Conceptual Framework.” Journal of International Management 14 (3):300-18.

Kuran, T. 1995. "Islamic Economics and the Islamic Sub-Economy." The Journal of Economic Perspectives 9 (4):155-73.

Lall, S. 2001. "Competitiveness Indices and Developing Countries: An Economic Evaluation of the Global Competitiveness Report." World Development 29 (9):1501-25.

Lawson, R. A., and J. S. Lemke. 2012. “Travel Visas.” Public Choice 153 (1-2):17-36.

Legrenzi, M. 2011. GCC and the International Relations of the Gulf: Diplomacy, Security and Economy Coordination in a Changing Middle East (Vol. 44). IB Tauris.

Looney, R. 1989. “An Economic Assessment of Bahrain's Attempts at Industrial Diversification.”

Mahdavy, H. 1970. "The Patterns and Problems of Economic Development in Rentier States: The Case of Iran Life," 1000, 1.

Mansfeld, Y., and O. Winckler. 2008. "The Role of the Tourism Industry in Transforming a Rentier to a Long-Term Viable Economy: The Case of Bahrain." Current Issues in Tourism 11 (3):237-67.

Mauro, P. 1995. “Corruption and Growth.” The Quarterly Journal of Economics, 681-712.

Mauro, P. 1998. "Corruption and the Composition of Government Expenditure." Journal of Public Economics 69 (2):263-79.

Mehlum, H., K. Moene, and R. Torvik. 2006. "Institutions and the Resource Curse." The Economic Journal 116 (508):1-20.

Meltzer, A. H., and S. F. Richard. 1981. "A Rational Theory of the Size of Government." The Journal of Political Economy, 914-27.

Mezher, T., D. Goldsmith, and N. Choucri. 2011. "Renewable Energy in Abu Dhabi: Opportunities and Challenges." Journal of Energy Engineering 137 (4):169-76.

Ménard, C., and M. M. Shirley, eds. 2005. Handbook of New Institutional Economics (Vol. 9). Dordrecht: Springer.

Miller, T., and A. B. Kim. 2013. Defining Economic Freedom. Edited by AT Miller, KR Holmes and EJ Feulner, 87-94.

Montinola, G., Y. Qian, and B. R. Weingast. 1995. "Federalism, Chinese Style: The Political Basis for Economic Success in China." World Politics 48 (01):50-81.

Morakabati, Y., J. Beavis, and J. Fletcher. 2014. "Planning for a Qatar Without Oil: Tourism and Economic Diversification, a Battle of Perceptions.” Tourism Planning \& Development (ahead-of-print), 1-20.

Myrdal, G. 1968. Corruption: Its Causes and Effects. Asian Drama: An Inquiry Into the Poverty of Nations, vol. 2, 953-61.

Niblock, T., and M. Malik. 2007. The Political Economy of Saudi Arabia. London: Routledge.

North, D. 1981. Structure and Change in Economic History. New York/London: W.W. Norton \& Company.

North, D. C. 1990. Institutions, Institutional Change and Economic Performance. England: Cambridge University Press.

North, D. C. 2008. "Institutions and the Performance of Economies Over Time." In Handbook of New Institutional Economics, 21-30. Berlin Heidelberg: Springer. 
Nuruzzaman, M. 2013. "Politics, Economics and Saudi Military Intervention in Bahrain." Journal of Contemporary Asia 43 (2):363-78.

Parolin, G. P. 2006. "Generations of Gulf Constitutions: Paths and Perspectives." In Constitutional Reform and Political Participation in the Gulf, 51.

Peterson, J. E. 2001. "Rulers, Merchants and Shaikhs in Gulf Politics." In The Gulf Family: Kinship Policies and Modernity.

Pirenne, H. 1937. Economic and Social History of Medieval Europe (Vol.14). Houghton Mifflin Harcourt.

Reed, D. 2001. Economic Change, Governance and Natural Resource Wealth: The Political Economy of Change in Southern Africa. London, Routledge: Earthscan.

Riker, W. H. 1964. Federalism: Origin, Operation, Significance, 31. Boston: Little, Brown.

Robinson, J. A., and D. Acemoglu. 2012. Why Nations Fail: The Origins of Power, Prosperity and Poverty. New York: Crown Publishers.

Rodden, J., and S. Rose-Ackerman. 1997. “Does Federalism Preserve Markets?” Virginia Law Review, 1521-72.

Rodrik, D. 1986. "Tariffs, Subsidies, and Welfare with Endogenous Policy." Journal of International Economics 21 (3):285-99.

Rodrik, D., A. Subramanian, and F. Trebbi. 2004. "Institutions Rule: The Primacy of Institutions Over Geography and Integration in Economic Development." Journal of Economic Growth 9 (2):131-65.

Romer, T. 1975. "Individual Welfare, Majority Voting, and the Properties of a Linear Income Tax." Journal of Public Economics 4 (2):163-85.

Ross, M. L. 2001. "Does Oil Hinder Democracy?” World Politics 53 (03):325-61.

Rubinfeld, D. L. 1997. “On Federalism and Economic Development.” Virginia Law Review, 1581-92.

Sachs, J. D., and A. M. Warner. 1995. "Natural Resource Abundance and Economic Growth (No. w5398)." National Bureau of Economic Research.

Sahib, A. S. A., and F. Kari. 2012. "Analysis of Intensity of Intra-Regional Trade in GCC Countries, 1998-2008." International Journal of Trade, Economics and Finance 3 (3):204.

Saif, I. 2009. The Oil Boom in the GCC Countries, 2002-2008: Old Challenges, Changing Dynamics. Carnegie Endowment for International Peace.

Sartawi, M. 2012. "State-Owned Enterprises in Kuwait: History and Recent Developments." Towards New Arrangements for State Ownership in the Middle East and North Africa, 93.

Schedler, A. 1999. “Conceptualizing Accountability." In The Self-Restraining State: Power and Accountability in New Democracies, 13-28.

Schlumberger, 0. 2000. Arab political economy and the European Union's Mediterranean policy: what prospects for development? New Polit. Econ. 5 (2):247-68.

Seligson, M. A. 2002. "The Impact of Corruption on Regime Legitimacy: A Comparative Study of Four Latin American Countries." The Journal of Politics 64 (02):408-33.

Shirley, M. M. 2005. Institutions and Development, 611-638. Springer US.

Spiess, A. 2008. “Developing Adaptive Capacity for Responding to Environmental Change in the Arab Gulf States: Uncertainties to Linking Ecosystem Conservation, Sustainable Development and Society in Authoritarian Rentier Economies." Global and Planetary Change 64 (3):244-52.

Sturm, M., J. Strasky, P. Adolf, and D. Peschel. 2008. "The Gulf Cooperation Council CountriesEconomic Structures," Recent Developments and Role in the Global Economy. ECB Occasional Paper (92). 
Tanzi, V., and H. Davoodi. 1998. Corruption, Public Investment, and Growth, 41-60. Tokyo: Springer.

TI Corruption Perception Index. 2014. Accessed from the website of http://www.transparency. org/cpi2014.

Tsai, I. 2013. "Carbon Capture, Utilization, and Storage Regulation in the Gulf Cooperation Council Countries: A Review on the Current Status." Economic and Social Commission for Western Asia (ESCWA).

Van Der Meulen, H. 1997. "The Role of Tribal and Kinship Ties in the Politics of the United Arab Emirates." Doctoral dissertation, Fletcher School of Law and Diplomacy.

Weingast, B. R. 1995. "The Economic Role of Political Institutions: Market-Preserving Federalism and Economic Development." Journal of Law, Economics, \& Organization, 1-31.

Wiktorowicz, Q. 1999. "The Limits of Democracy in the Middle East: The Case of Jordan." The Middle East Journal, 606-20.

Yamada, M. 2011. "Gulf-Asia Relations as "Post-Rentier" Diversification? The Case of the Petrochemical Industry in Saudi Arabia." Journal of Arabian Studies 1 (1):99-116.

Yates, D. A. 1996. The Rentier State in Africa: Oil Rent Dependency and Neocolonialism in the Republic of Gabon. New Jersey: Africa World Press.

Zhang, T., and H. F. Zou. 1998. "Fiscal Decentralization, Public Spending, and Economic Growth in China." Journal of Public Economics 67 (2):221-40. 